\title{
GASPAR BARTHOLINUS AND THE VULVOVAGINAL GLANDS
}

Female semen, the name once applied to the fluid that issues from the woman's genitals during coitus, was assumed for many years to originate in the female testes, as the ovaries were called. This fluid, regarded as essential to fecundation since the time of Aristotle, was thought to discharge into the urethra, as in the male. Herophilus, whose original writings are all lost, but some of which had been copied down by Galen and incorporated into the latter's writings, believed that he had traced the course of the seminal ducts from the female testes to the bladder. In Galen's De Semine, Herophilus is quoted as follows: 'A very small seminal duct occurs on each side, arising from the uterus. The first part of this duct is much folded, and as in males it runs from the testicle to the fleshy part of the neck of the bladder.' Corner ${ }^{3}$ has suggested that this description is based on an examination of the genitalia of a sow with persistent Wolffian or Gartner ducts, not rare in this species. The true source of the female semen was not recognized until the latter part of the seventeenth century. Following the discovery of the vulvovaginal glands in cattle by Duverney, one of his contemporaries, Caspar Bartholinus, in 1677 first called attention to, and described the functions of, these glands in women.

The paraurethral ducts had recently been described by de Graaf in his De mulierum organis ${ }^{4}$ as the portal of exit of the fluid that lubricates the introitus and stimulates libido.

These, [wrote Bartholinus, referring to the ducts through which the female semen was believed to empty into the urethra] I did not judge adequate for this function, but elsewhere in the vicinity of the urethral meatus and the vaginal orifice I saw larger openings which, after careful consideration, I judged to be better suited for carrying off the fluid from the gland which is nearly analogous to the male prostate, the ducts of which empty into the urethra, as described by Graaf. Examining these structures again more closely in cows, I discovered in these animals, near the walls of the vagina and not far from the urethral orifice a prominent gland on both sides which drains into the vaginal canal; and when the gland is pressed, the protuberant ostium opens conspicuously in a nipple within the vulva.... It is composed of many glands and covered entirely with its own fleshy fibers; and the great secret of nature which I discovered is that this fluid does not flow freely except during coitus or masturbation, nor can the ostia be found except when the nipple protrudes. Therefore, since the fluid cannot be drained off unless the nipple protrudes, nature adds fleshy fibers which compress the glands during the venereal act so that the nipples protrude and the fluid may be discharged. The fleshy fibers are seen to arise near the vesical sphincter like the prostates of men, which are also covered by small muscle fibers which originate and spread out from the bladder sphincter, according to Graaf. This gland, which is to be seen 


\section{Newe, Notes and Queries}

on either side, is made up of many parts and excretions flow from it in large quantity into the nipple, which protrudes when the gland is compressed; otherwise it retracts, leaving hardly a trace of itself. One finds that these excretory ducts, where they discharge through their ostium, are distended when a catheter is inserted, and the ducts ramify into various branches to the periphery of the gland, as is observed in the excretory ducts of other glands; the ducts gradually decreasing in caliber in the various ramifications (which are of course in the substance of the gland) and ending. Moreover one might say that connected to the glands are vesicles or small elongated sacs in which the fluid secreted in the glands is stored and then discharged. ${ }^{1}$

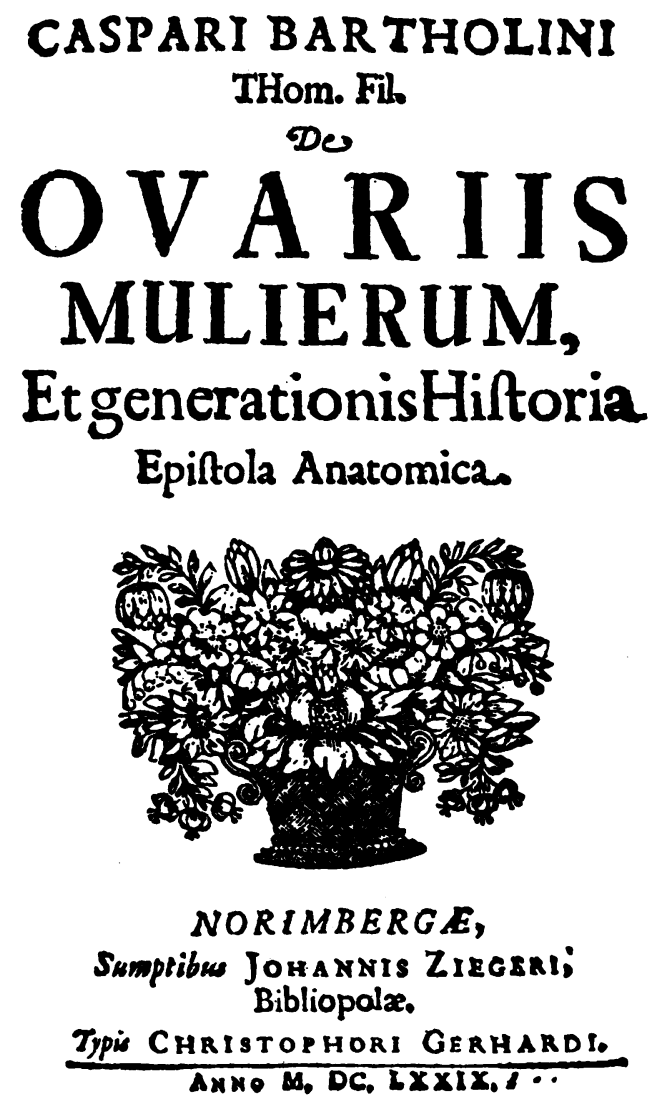

Since this description, Bartholin's name has become so intimately identified with the vulvovaginal glands that these structures are seldom called by any other name than Bartholin's gland, a term which is occasionally applied to a division of the sublingual gland as well. In recent years the tendency has grown to drop the word gland when referring to affections of the vulvovaginal gland, so that the terms Bartholin cyst and Bartholin abscess are 


\section{News, Notes and Queries}

now in common use; and inflammations of the organ, properly termed Bartholin adenitis, are now acceptably written as bartholinitis, with a small b. ${ }^{5}$

Caspar Bartholinus, Junior, was born in Copenhagen in 1655 , into a family of scientists of long distinguished reputation (Table $\mathrm{I}$ ). It is probably his father, Thomas, to whom Dissertatio de cygni anatomia should properly be

Caspar, Primus (I 585-1629)

Theologian and Physician, married Anna, daughter of Thomas Fincke ( $\left.15^{6} 1-165^{6}\right)$,

Methematician and Physician.

(i)

Jacob

-1653 )

Orientalist (i)

Caspar,

Secundus

(1655-1 738)

Anatomist

\author{
(ii)
}

Thomas, Primus

(1616-80)

Anatomist, originally

Professor of

Mathematics (iii)

Erasmus

(1625-98)

Physicist (iv)

Albert

Bibliographer (iii)

Margaret,

Poetess
Also three other

distinguished sons
Thomas,

Secundus

(1659-9o)

Distinguished for

his literary works

TABLE I

NOTE ON THE BARTHOLIN FAMILY

(from Dobson, J. Anatomical Eponyms. London. Baillière, Tindall \& Cox. 1946, p. 25.)

attributed, for Caspar was only thirteen years old at the time of its publication in $1668 .^{2}$ Yet this treatise is believed to have paved the way for his appointment by the King as Professor of Philosophy at the age of nineteen, only three years after he matriculated as a student. Following a three-year tour of various universities in Holland, France, Italy, and Germany, he returned to Copenhagen in 1677 , when his famous De Ovariis Mulierum was published. As Professor of Physic he now proceeded to give lectures in anatomy while carrying on his own investigations, which were largely based on the previous work of his teachers Ruysch, Swammerdam, and particularly Steno. 


\section{News, Notes and Queries}

Bartholinus was a man of wide interests and great versatility; and as a result of the many demands made upon him he found less and less time for his teaching and research. By I 7o I his active participation in the work of the medical faculty had practically ceased, while he found himself in such positions as assessor of the highest tribunal, later Procurer-General, and ultimately Deputy for Finance. In recognition of these efforts on behalf of the government, he received many decorations, and in $173 \mathrm{I}$, together with his father and all his descendents, was elevated to the nobility. Even after the cessation of his medical and teaching activities, however, and for the ensuing thirty-seven years, despite the resentment of his medical colleagues, he retained both his professorial rank and salary and continued to occupy a position second only to the dean of the medical faculty until his death in I $73^{8}$.

Department of Obstetrics and Gynecology,

HAROLD SPEERT

Columbia University.

\section{REFERENCES}

I. Bartholinus, C. De Ovariis Mulierum, et Generationis Historia. Nuremberg, Joahnn Zieger, 1679, pp. 19-21. (The first printing was in Rome in 1677.)

2. Hirsci, A. Biographisches Lexikon der heroorragenden Xrzte aller Zeiten und Völker. 2te Aufl. Berlin and Vienna, Urban \& Schwarzenberg, I929, I, 358-59.

3. Corner, G. W. 'The discovery of the mammalian ovum.' In Lectures on the History of Medicine. A series of Lectures at the Mayo Foundation ... 1926-32. Philadelphia, W. B. Saunders Co., 1933, pp. 401-26.

4. Gra A F, R. DE. De Mulierum Organis Inservientibus. Leyden, 1672.

5. Stedman's Practical Medical Dictionary. I6th ed. Baltimore, Williams \& Wilkins, 1946, p. 13 I.

\section{BOOKS ON MEDIGAL HISTORY}

The following question is submitted to the readers of Medical History, by Dr. Iago Galdston, Secretary, Medical Information Bureau, New York Academy of Medicine: 'If you had no more than $\$ 250.00$ to spend in the purchase of a small working library on medical history, what books would you select?' British readers can regard the sum available as being equal to approximately $£ 80-f 90$, and as prices vary it is not necessary to work out the exact equivalents for all items. Selection need not be confined to works in English. Any readers who care to take part in this exercise in book selection are asked to send their lists to the Editor. The replies will be collated and the result published in Medical History in due course. 